\title{
Treatment of Individuals with Disabilities throughout History and across Religions in Libya
}

\author{
Zeinab Abulhul1,2 \\ ${ }^{1}$ Department of Center for Social Work Education, School of Health and Human Services, Widener University, Chester, PA, USA \\ ${ }^{2}$ Department of Social Work, University of Tripoli, Tripoli, Libya \\ Email: Zaino,abulhul@gmail.com
}

How to cite this paper: Abulhul, Z. (2020). Treatment of Individuals with Disabilities throughout History and across Religions in Libya. Open Journal of Social Sciences, 8 , 207-218.

https://doi.org/10.4236/jss.2020.811019

Received: October 20, 2020

Accepted: November 21, 2020

Published: November 24, 2020

Copyright $\odot 2020$ by author(s) and Scientific Research Publishing Inc. This work is licensed under the Creative Commons Attribution International License (CC BY 4.0).

http://creativecommons.org/licenses/by/4.0/

\section{(c) (i) Open Access}

\begin{abstract}
This article describes historical eras' and religions' influences on Libyan people's attitudes toward individuals with disabilities. This article depicts the emergence of ancient civilizations and religions (e.g. the Pharaoh era, the Greek and Roman Empires, Arab immigrant civilizations, and the Ottoman and Italian Empires) in Libya and assesses how these civilizations' cultures have shaped Libyan people's opinions toward and acceptance of people with disabilities. This article also reviews the Libyan literature about disabled people throughout the country's history. In doing so, this study describes the impact of ancient civilizations on Libya's current population. It also expresses the impact of divine religions and contemporary invasions. Ultimately, this article is intended to raise people's awareness of fair advocacy for people with disabilities' rights.
\end{abstract}

\section{Keywords}

Treatment, People, Disabilities, Libya, Mediterranean Sea, Religions, Children, Social

\section{Introduction}

Libya is considered one of many countries with ethical legislation in place to uphold the rights of people with disabilities. However, this support has existed much more prominently in theory than in practice. In reality, Libyan society does not significantly support individuals with disabilities. On many occasions, individuals with disabilities are hidden from their communities, and many parents feel ashamed when they allow their disabled children to participate in the 
social sphere. Libyans perceive the integration of individuals with disabilities into Libyan social life as very challenging. Their integration requires immense support, which can be fostered in part by raising Libyans' awareness and encouraging individuals with disabilities to participate with people without disabilities in their everyday lives. In turn, non-disabled individuals might defend the rights of disabled individuals, who, as Libyan citizens, have the right to enjoy their lives and to be respected (Crabtree \& Williams, 2011).

\section{Individuals with disabilities in Libyan law}

In this analytical study, the term "people with disabilities" is based on the definition given in Libyan law. People with disabilities are individuals who have either a partial or total impairment that prevents them from living a normal life. Their disabilities might be physical, emotional, or mental, and they might be genetic or acquired. The term "people with disabilities" also applies to people living with a mental illness, blindness, deafness, or dumbness, as well as the visually impaired, hearing impaired. Also, people who have had a body part amputated and those who have been paralyzed fall into this group. Depending on their situation, people with disabilities are legally entitled to governmental benefits, such as financial aid or in-kind assistance (Disabilities Law No. 5, 1987).

Libya is located in North Africa, situated between Egypt and Tunisia. It has a long coastline along the Mediterranean Sea, which attracted many ancient civilizations, such as the Greeks and Romans (Stahl, 2014). Missionaries helped spread Judaism, Christianity, and Islam throughout the area. These old civilizations and religions starting from the Pharaoh era, continuing into the Greek and Roman eras, the period of Arab Immigration, and the spread of divine religions significantly shaped Libyan people's customs and traditions (Figure 1). Even though most of the current population is Muslim, the varied influences of other civilizations can be seen from the short time they spent with the country's people.

\section{Disabled People in Ancient Eras}

\section{Pharaoh's time}

Libya ruled over part of Egypt in the eastern Delta in 945 BC when Eastern Libya was located on Egyptian land. There was a kin relationship between the Berber (Amazigh) nation and the Pharaohs' dynasty. That kin relationship authorized Pharaohs Libyan Berber to pass along his power to Libyan Berber (Amazigh), who became a powerful ruler called Sheshonq I and who ruled ancient Egypt for 200 years in the third intermediate of the pharaonic period, which was called Dynasty 22 during that time (Allen, 2018; Nesmenser, 2016b).

Symbols of this ancient time remain to this day as images on mountains and in caves in the Libyan desert. In the Pharaoh era's old kingdom, many depictions of images on mountains and caves in the Libyan desert depict that vulnerable individuals, such as disabled individuals and widowers, received care and attention from pharaohs. There were two dwarf gods, Bes and Ptah, and they were 


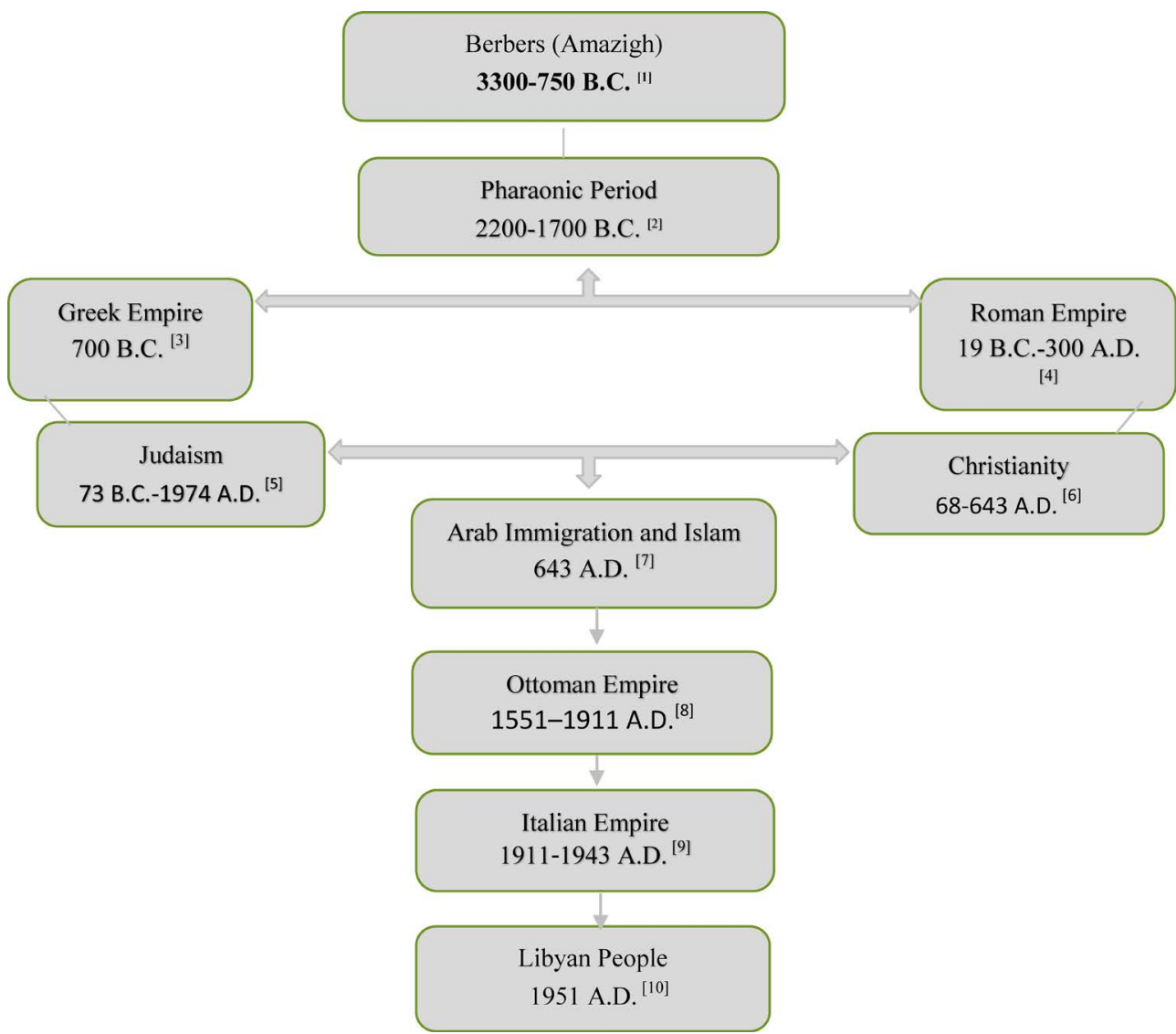

Note: This Figure depicts the timeline of individuals with disabilities across history and religions in Libya. [1] (Nesmenser, 2016a). [2] (Oyeniyi, 2019: p. 5). [3] (Stahl, 2014). [4] (Ratnikas, n.d.). [5] (JIMENA, 2020). [6] (Oden, 2011). [7] (Chapin, 1991). [8] (Nesmenser, 2016b). [9] (Pasquale, 2018). [10] (The Library of Congress Country Studies, 2001).

Figure 1. Timeline of different civilizations' control of Libyan land.

not considered disabled, they were considered favored by the gods, and it was believed that they should be respected-dwarfs especially were considered favored by the gods. Perhaps this was the case because ancient people in the Pharaoh era did not question their gods. Their obedience to their gods might have helped them accept disabled individuals with love and without judgment. Thus, religious men in temples protected disabled individuals and provided them with financial assistance (Mohammed, 2014; Temehu Tourism Services, 2019; Hardy, 2018; Mahran \& Kamal, 2016; Kozma, 2006).

However, some literature discusses opposing conditions. It has been indicated that the Pharaoh ordered children, especially vulnerable males, to be killed. As part of this order, the Prophet Moses was targeted to be killed, but Moses was protected from that order. Infanticide was not a crime at this time, and parents would kill their children if they could not secure food for them or otherwise take care of them (Miller \& Wright, 2013).

However, most ancient documents describe that, in general, disabled persons were accepted at the beginning of the Pharaoh era and were helped and protected per the culture and pharaonic religion. It might be that some negative at- 
titudes appeared near the end of the Pharaoh era. It could be that people's attitudes began to be influenced by the Greeks after they made contact with Pharaohs in north Africa (Center for Hellenic Studies, n.d.) and conquered Libya, where their empire flourished.

\section{Greek and Roman eras}

As Greek religion migrated to Italy, the Greeks started to settle in southern Italy, where the Hellenic civilization (which became the Roman Empire) arose (Macbeth, 2018; Center for Hellenic Study, n.d.). Later, the Greeks found that North Africa was an ideal place for their trade to thrive and for their empire to expand. Thus, they founded six ancient Greek cities on the coast of the Libyan Sea in 630 A.D.: "Euhesperides (modern Benghazi), Taucheira, Barca, Ptolemais, Apollonia" (Lendering, 2019, para. 1), and their capital of Cyrene.

At that time, the Greek and Libyan people were friendly with each other, and intermarriages between men and women of both nations commonly took place. As social relationships developed among the two nations, people began sharing their norms and customs. Intermarriages mixed the Libyan and Greek cultures. The effects of this mixing of cultures can still be seen today in some customs related to food or the actions taken on some social occasions (Lendering, 2019).

Later, Libyan land became occupied by the Roman Empire, which invaded Libya around the $1^{\text {st }}$ century A.D. The Romans turned Libya into part of their armed empire, making Libya an essential part of the Roman Empire. Libyan land was favorable for agriculture and was a choice location for trade, making it a suitable place for the Romans to inhabit. These people used exiled Jews to work on Libyan land to boost trade, increase crop yields, and meet the Roman Empire's needs.

Septimus Severus was the first Libyan-born emperor, and he ruled Libya from 193 to 211 (Dossey, 2010; Jerary, 2003; Land, 2018). The ancient people who immigrated to Libya from Greece and Rome coexisted with the Libyans for a long time-whether they were friendly with Libyans, like the Greeks, or adversarial, like the Romans. Together, these immigrants impacted the Libyan people, who absorbed many aspects of their cultures. Over time, these foreign cultures impacted Libyans' perceptions of social values. We can still see such effects in some social customs today.

In the Greek and Roman times, it was believed that children who were disabled were unwanted by the gods and that their disabilities were forms of punishment for misbehavior and sin. The gods wanted these children to suffer and die during their infancy; if they lived, they were "buffoons" who entertained the people (Auman et al., n.d.). The ancient Greeks believed that children with disabilities were the result of an evil force (Smeltzer et al., 2017).

Therefore, children with disabilities were not fortunate; they were treated as unhuman, and it was acceptable for others to harass them. Such behavior led to no guilt or blame, as many people viewed the harasser as humorous. In addition, children with disabilities were often killed in the cradle. In ancient Greece, when 
a disabled infant was born, the family had to wait ten days to hear an announcement from the elders of their tribe regarding whether they would kill the infant to prevent the family from stigmatization or keep it (Penrose, 2015) to serve as a beggar. If the child was to be kept, they might be hurt to increase the severity of their impairment, thus making them more suitable for their work as a beggar. Some families who did not see any value in their disabled children left them in the woods without food to die from starvation or to be eaten by predators. If they were lucky, a passerby might adopt them or take them in as a servant. Individuals with disabilities were also often used in war; however, they were made to fight without any resources, and so they were usually killed.

Greek society perceived disabled individuals as a burden to society. Thus, it was believed that such individuals needed to prove that they could survive if they were to be allowed to live. Because of this, many parents who wanted to keep their disabled children hid them and protected them from being hurt or stigmatized (The Minnesota Governor's Council on Developmental Disabilities, 2019; Laes, 2008; Penrose, 2015; Albrecht et al., 2001).

The attitude of ancient Libyan people toward people with disabilities was not easily changed when Arab immigrants came to spread Islam throughout North Africa. This occurred during the end of the Greek and Roman Empires until Islam spread and encouraged people to follow the Islamic instructions.

\section{Arab immigration to Libya}

Before the Arabs immigrated to Libya to work as Islam missionaries at the end of the 6th century, most Libyan people were Berber natives (AlKroud, 2018). Berber people inhabited the entire continent of Africa. They had settled along rivers before the era of the pharaohs. The word "Berber" originated from invaders who perceived the Libyans as brave because of the way they fought to protect their land.

Around the time when the Arabs immigrated to Libya, the Libyans called themselves "Amazighen", which means "free men" (Oyeniyi, 2019: p. 5). They practiced Judaism and Christianity, which had been brought to the area by the Greeks and Romans. When the Islam missionaries came to North Africa to spread Islam as the last divine religion after Judaism and Christianity, most Berbers welcomed Islam and became Muslim. The Arab missionaries settled in the area and conquered it so that they could teach Islam to the native people. Therefore, they brought with them many Arab teachers, who taught the Arabic language to the Libyan people so that they could understand and learn the Quran (Fitzgerald, 2016).

However, subsequent cohorts of Arabic missionaries were focused not only on spreading Islam but also on spreading the Arabic culture, which eventually came to dominate the Berber culture. Gradually, the Berbers' identity and language were dismissed due to their integration into Arabic identity. To this day, many Berbers are still working to retrieve their identity (Haschke, 2011).

The ancient Arabic culture's general attitude toward disabilities undermined 
disabled individuals. Disabled individuals were considered a burden to society because they could not contribute to meeting the needs of their tribes by hunting, gathering fruits, or defending against invasions (Nazar, 2014). Thus, they were considered an inferior class. Many Arabs honor the healthy body, and their tribes were proud of their healthy men; for instance, they held knights who could ride horses and win horse races in high regard. As such, disabled individuals were not accepted in Arab society (Gaddafi, 1988). In some cases, people buried disabled infant girls or threw stones at disabled boys to free themselves from what they believed were reincarnated demons (Medhat, 2009).

\section{Disability in divine religions}

Libya was invaded by the Greek, Roman, and Arab empires, each of which brought religions, including Judaism, Christianity, and Islam. The religious influences of these empires can still be seen in Libyan customs and culture today.

Disability in Judaism: According to Judaic tradition, Moses provided clear instructions in the Torah that Jews are responsible for taking care of people with disabilities. Specifically, the Jews are to provide services to meet disabled individuals' needs and help integrate them into society without discrimination. As stated in Leviticus, chapter 19, verse 14, "You shall not insult the deaf, or place a stumbling block before the blind" (Religious Action Center of Reform Judaism, para. 2, n.d.).

Disability in Christianity: Christianity supports the integration of people with disabilities with all other people and professes that people should help them to live their lives. Many instances exist in the gospels in which Jesus mandates that people should appreciate the disabled and should be humble with those who are disabled because they are created from God just as everyone else is. Their disability does not reflect their sins, and their disabilities are not a form of punishment from God. This idea is illustrated in John 9: 1-3: "As [Jesus] passed by, he saw a man blind from birth. And his disciples asked him, 'Rabbi, who sinned, this man or his parents, that he was born blind?' Jesus answered, 'It was not that this man sinned, or his parents, but that the works of God might be displayed in him"' (Bayes, 2015, para. 25). Additionally, as Leviticus 19:14 states, "You shall not curse the deaf or put a stumbling block before the blind, but you shall fear your God: I am the Lord" (OpenBible, n.d.).

Disability in Islam: Islam has had a significant impact on people's attitudes and perceptions of disability, as well as on how people should communicate with individuals with disabilities. Islam proposes that people with disabilities should be made to feel like they are a part of society and that their rights and participation in society should be ensured (Guvercin, 2008). In addition, Islam stresses that a person should be righteous, which starts by achieving closeness to God and not being arrogant. A proud person who belittles others because of their physical or mental impairments does not please God.

The Quran mentions that God gave permission to disabled individuals to practice and worship according to their capacity and that they are not to be 
compared to other worshippers. It is stated that God accepts their deeds with an appreciation for their efforts (Bhatty et al., 2009). Many Quran verses call for people to behave properly, appreciate one another, and refrain from undermining those with disabilities. Instead, they are urged to help them because we do not know who is close to God-only God knows (Ghaly, 2016). The Quran warns against and forbids committing infanticide because of an impairment. This practice is referred to as an abomination in its verses (الأنعام 137):

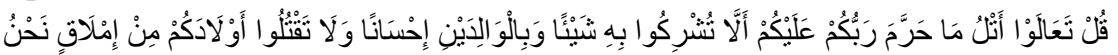

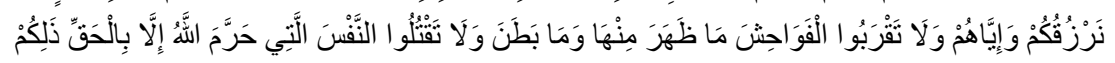

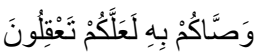

"And do not kill the soul which God has forbidden except for the requirements of justice..." [Glorious Qur'an, Al-An'am 8: 151] (Al-Matary \& Ali, 2014, para. 14). In addition, society should prevent the killing or harming of individuals with disabilities, protect their dignity, and ensure that their rights are upheld (Bengtsson, 2018). The Quran's verses also emphasize that the value of a person is not related to appearance, economic success, or social status. Instead, one's value is assessed based on how a person follows God's instructions, which is related to the deeds a person performs on Earth and their efforts to spread peace by helping others. Such acts bring a person close to God, and they are rewarded for them in heaven. The Quran states that a person's weakness is not derived from having impairments but rather from performing evil deeds (Rights of the Disabled, n.d.).

Islamic history provides many examples of appreciation for disabled individuals in Muhammad the Prophet's life and their influences on the Muslim people. For example, even though Abdullah ibn Umm Maktoum was blind, he still memorized the Quran and was appointed by the Prophet Muhammad to be a caller to pray five times a day. He was only the second person to receive this honor. As another example, Julaybib had an unpleasant face, and so no parent would allow him to marry their daughter. He went to the Prophet Muhammad for help, and the Prophet Muhammad represented him. He called upon several men and asked them who would marry his daughter to this man. Many honorable families then competed to marry their daughters to Julaybib because he was represented by the Prophet. As a result, he married the daughter of an honored family (Guvercin, 2008).

Disabled individuals were not distinguished or separated from non-disabled individuals at the beginning of Islam. Even after the Prophet Muhammad died, people continued to follow the prophet Muhammad's instructions, and they attended to disabled individuals. Omar ben al-Khattab, a role model for Muslims and their third leader, saw that disabled people could not reach the mosque easily. So, he provided them with a house close to the mosque to make the mosque more accessible to them. Also, Islam encourages Muslims to improve their society and its conditions and inspires them to help each other and protect the rights of vulnerable people, including disabled persons (Al-Aoufi, Al-Zyoud, \& 
Shahminan, 2012).

The influence of religions continued in subsequent generations following the invasions of the Ottomans and Italians, who believed in the divine religion.

\section{The Ottoman Empire and the Italian Empire}

After the overthrow of the Knights of Malta in 1551, Libya was occupied by the Ottoman Empire, as were several other countries in North Africa (Maddex, 2007). The Ottomans' perception of disabilities was influenced by Islamic culture; they considered deafness and blindness not as disabilities but as misfortunes. They saw individuals who could not take responsibility for themselves, such as individuals with mental illness, as minors who could not be charged for their behaviors (Scalenghe, 2014). Libya remained under Ottoman rule from 1711-1911. This period witnessed many rebellions, both in favor of and against the Ottoman regime's dominance of Libya. Because the Ottoman Empire ruled over many countries in North Africa, it was difficult for them to control their colonies despite the heavy presence of armed campaigns that were sent to inhibit rebellions throughout the region.

Eventually, the Ottoman Empire entered a conflict with Italy as Italy looked to expand its authority in the area surrounding the Mediterranean Sea. As a result, Italy ruled Libya from 1910-1943 (Chapin, 1989). The Italians perceived disabled people as shameful, and this perception forced disabled individuals to hide from non-disabled individuals. It seems the influence of old the Greek and Roman Empires persisted in the following generations. This occurred even though religion banned people from belittling those with disabilities and professed that they should instead be well respected and assisted. This situation also appears nowadays continued agreements with European legislation stating that disabled individuals should be protected and provided with education and work opportunities so that they can be independent. Nevertheless, they still struggle to receive their full rights (Mura, 2014; Italy Part 1: Facts and Perceptions, 2018; Allotey et al., 1997).

\section{Conclusion}

This article explored the influences that ancient civilizations (and their belief systems) have had on Libyan people's attitudes toward and treatment of people with disabilities. The Libyan people have been influenced by several groups of people due to the country's advantageous location. Being located along the Mediterranean Sea in North Africa, Libya attracted the ancient Greeks and Romans, who wanted to expand their empires.

The characteristics of the old lifestyles of ancient people and positivist and divine religions continue to influence the Libyan population's attitudes today. The present article explored many such influences, starting from the Pharaoh era, continuing into the Greek and Roman eras, the period of Arab Immigration, and the spread of divine religions. This work also includes an illustration of the influence of the Ottoman and Italian Empires on Libyan attitudes towards people 
with disabilities. This exploration makes it clear that current Libyan attitudes toward individuals with disabilities are the result of the diversity of the Libyan people's historical and religious roots.

The present research may have implications for Libyan social workers who work in the Healthcare Department, Educational Department, and Social Security Department Fund. By raising awareness of the importance of helping disabled people among Libyan people from all levels of society (i.e. by accepting them in public and including them in daily social life), non-disabled individuals can help disabled individuals learn social skills, become independent, and involve themselves in public life.

\section{Conflicts of Interest}

The author declares no conflicts of interest regarding the publication of this paper.

\section{References}

Al-Aoufi, H., Al-Zyoud, N., \& Shahminan, N. (2012). Islam and the Cultural Conceptualisation of Disability. International Journal of Adolescence and Youth, 17, 205-219. https://www.tandfonline.com/doi/full/10.1080/02673843.2011.649565 https://doi.org/10.1080/02673843.2011.649565

Albrecht, G.L., Seelman, K., \& Bury, M. (2001). Handbook of Disability Studies. Sage Publications, Inc.

https://books.google.com/books?id=vAKSZPR-hk0C\&printsec=frontcover\&dq=Handb ook + of + Disability + Studies\&hl $=$ en \&newbks $=1$ \&newbks_redir $=0 \& s a=X \& v e d=2$ ahUKE wj3zaHOzKfoAhXelXIEHUsUBD0Q6AEwAHoECAQQAg\#v=onepage\&q=Handbook \%20of\%20Disability\%20Studies\&f=false

AlKroud, E. A. (2018). Renarrating the Berbers in Three Amazigh Translations of the Holy Quran: Paratextual and. Framing Strategies. Manchester: School of Arts, Languages and Cultures, University of Manchester. https://pdfs.semanticscholar.org/93d0/989ed31d3e6f6f5108ba70b5512ce3794229.pdf

Allen, J. (2018). Egypt in the Third Intermediate Period (ca. 1070-664 B.C.). https://www.metmuseum.org/toah/hd/tipd/hd_tipd.htm

Allotey, P., Manderson, L., Nikles, J., Reidpath, D., \& Sauvarin, J. (1997). A Guide for Health Professionals. Australian Centre for International and Tropical Health at the University of Queensland.

https://www.health.qld.gov.au/_data/assets/pdf_file/0017/154610/italian.pdf

Al-Matary, A., \& Ali, J. (2014). Controversies and Considerations Regarding the Termination of Pregnancy for Foetal Anomalies in Islam. BMC Medical Ethics, 15, Article No.: 10. https://doi.org/10.1186/1472-6939-15-10

Auman, L., Edmond, G., Kundrata, J., Pearson, N., \& Rehkopf, C. (n.d). Early History. Disability Discrimination.

https://sites.google.com/a/une.edu/disability-discrimination2011/history

Bayes, R. (2015). A Biblical View of Disability. Bethinking. https://www.Bethinking.org/human-life/a-biblical-view-of-disability

Bengtsson, S. (2018). Building a Community: Disability and Identity in the Qur'an. Scandinavian Journal of Disability Research, 20, 210-218. https://doi.org/10.16993/sjdr.18 
Bhatty, I., Moten, A., Tawakkul, M., \& Amer, M. (2009). Disability in Islam: Insights into Theology, Law, History, and Practice.

https://www.researchgate.net/publication/270893538_Disability_in_Islam_Insights_int o_Theology_Law_History_and_Practice

Center for Hellenic Study (n.d). Early Greek Contact with Africa. Harvard University https://chs.harvard.edu/CHS/article/display/6537.1-early-greek-contact-with-africa

Chapin, H. M. (1989). Libya: A Country Study(4th ed.). Library of Congress. Federal Research Division. https://lccn.loc.gov/88600480

Chapin, H. M. (1991). Sudan, A Country Study. Washington: GPO for the Library of Congress. http://countrystudies.us/sudan/

Crabtree, S., \& Williams, R. (2011). Ethical Implications for Research into Inclusive Education in Arab Societies: Reflections on the Politicization of the Personalized Research Experience. International Social Work, 56, 148-161. https://doi.org/10.1177/0020872811416486

Dar al-Iftaa Al-Missriyyah (n.d). Rights of the Disabled. http://www.dar-alifta.org/Foreign/ViewArticle.aspx?ID=4961\&CategoryID=5

Disabilities Law No. 5 (1987). Children with Disabilities Act (Art. 23). http://aladel.gov.ly/home/?p=1211\%221211

Dossey, L. (2010). Peasant and Empire in Christian North Africa. Berkeley: University of California Press.

Fitzgerald, H. (2016). The Berbers and Islam as a Vehicle for Arab Supremacism. New English Review.

https://www.newenglishreview.org/Hugh_Fitzgerald/The_Berbers_and_Islam_as_a_Ve hicle_for_Arab_Supremacism/

Gaddafi, M. (1988). Sayakulujiat al'iieaqa [Psychology of Disability]. Aldaar alearabiat lilkitab. الدار العربية للكتاب. Libya.

Ghaly, M. (2016). Disability in the Islamic Tradition. Religion Compass, 10, 149-162. https://doi.org/10.1111/rec3.12202

Guvercin, H. (2008). People with Disabilities from an Islamic Perspective. Fountain, No. 63.

https://fountainmagazine.com/2008/issue-63-may-june-2008/people-with-disabilities-f $\underline{\text { rom-an-islamic-perspective }}$

Hardy, O. (2018). Disability in Ancient Egypt and the Disabled Pharaoh. Hands Free Computing. https://www.hands-free.co.uk/disability-ancient-egypt-disabled-pharaoh/

Haschke, P. (2011). The Affirmation of the Amazigh Identity as Part of Morocco's Patrimony. United Nations Alliance of Civilizations [UNAOC].

https://www.unaoc.org/2011/10/the-affirmation-of-the-amazigh-identity-as-part-of-m orocco\%E2\%80\%99s-patrimony/

Italy Part 1: Facts and Perceptions (2018). Disability Around the World Blog. https://sites.psu.edu/rhs100fa18001/2018/10/05/italy-part-1-facts-and-perceptions/

Jerary, M. T. (2003). Septimius Severus the Roman Emperor, 193-211 AD. Istituto Italiano per l'Africa e l'Oriente (IsIAO). https://www.jstor.org/stable/25734499

JIMENA (2020). Timeline. http://jimenaexperience.org/libya/timeline/

Kozma, C. (2006). Dwarfs in Ancient Egypt. American Journal of Medical Genetics Part $A, 140 A$, 303-311. https://doi.org/10.1002/ajmg.a.31068

Laes, C. (2008). Learning from Silence: Disabled Children in Roman Antiquity. Arctos, $42,85-122$. 
https://www.academia.edu/11459903/Learning_from_Silence_Disabled_Children_in_R oman_Antiquity_in_Arctos_42_2008_p._85-122

Land, G. (2018). The Marvel of North AFRICA during Roman Times. History Hit. https://www.historyhit.com/the-marvel-of-north-africa-during-roman-times/

Lendering, L. (2019). Cyrenaica. Livius.org. https://www.livius.org/articles/place/cyrenaica/

Macbeth, A. (2018). Four Civilizations in Italy That Pre-Date the Roman Empire. https://www.thelocal.it/20180911/four-civilizations-in-italy-that-pre-date-the-roman-e mpire

Maddex, R. L. (2007). Constitutions of the World. SAGE Publications. https://books.google.com/books?id=YaA5DQAAQBAJ\&newbks=1\&newbks_redir=0\& printsec $=$ copyright\&source $=$ gbs_pub_info_r\#v=onepage\&q\&f=false https://doi.org/10.4135/9781452240091

Mahran, H., \& Kamal, S. (2016). Physical Disability in Old Kingdom Tomb Scenes. Athens Journal of History, 2, 169-192. https://doi.org/10.30958/ajhis.2-3-2

Medhat, N. (2009). Rieayat Watahil Almueaqin [Care and Rehabilitation of the Disabled]. Cairo: Global Links for Publishing and Distribution. https://books.google.com/books?id=iyiBDwAAQBAJ\&pg=PA21\&lpg=PA21\&dq=\%D8 \%A7\%D9\%84\%D9\%85\%D8\%B9\%D8\%A7\%D9\%82\%D9\%8A\%D9\%86+\%D9\%81\%D9 \%8A+\%D8\%A7\%D9\%84\%D8\%AC\%D8\%A7\%D9\%87\%D9\%84\%D9\%8A\%D8\%A9\&so urce $=$ bl\&ots $=\mathrm{yK} 2 \mathrm{~B} 5 \mathrm{Ex}-$

Miller, J., \& Wright, R. (2013). Encyclopedia of Criminology.

https://books.google.com/books?id=GsZiAgAAQBAJ\&pg=PA166\&lpg=PA166\&dq=mi streated

https://doi.org/10.4324/9780203942796

Mohammed, A. (2014). Damj alaihtiajat alkhasat fi altaelim aleami [Integrating Special Needs into General Education]. المجموعة العربية للتنريب والنشر, Group Arab. https://books.google.com/books?id=VvVhDwAAQBAJ\&pg=PA14\&lpg=PA14\&dq\#v= onepage \&q\&f=false

Mura, A. (2014). Associations for Disabled People in Italy: A Pedagogical Exploration. Alter, 8, 82-91. https://doi.org/10.1016/j.alter.2014.03.002

Nazar, B. (2014). Harakat huquq almueaqin.. nazrat tarikhia [The Movement for the Rights of Persons with Disabilities... a Historical View]. Al-Manal Magazine. https://almanalmagazine.com/\%D9\%88\%D8\%AC\%D9\%87\%D8\%A9-\%D9\%86\%D8\%B 8\%D8\%B1/\%D8\%AD\%D8\%B1\%D9\%83\%D8\%A9-\%D8\%AD\%D9\%82\%D9\%88\%D9\% $\underline{82-}$

Nesmenser, B. (2016a). Libyan People. Temehu, Zuwarah, Libya. https://www.temehu.com/Libyan-People.htm

Nesmenser, B. (2016b). The Native Berbers of the Ancient Egyptian Period: 3300 BC to 750 BC. https://www.temehu.com/History-of-Libya.htm

Oden, T. (2011). Early Libyan Christianity: Uncovering a North African Tradition. InterVarsity Press.

OpenBible.info. (n.d). 100 Bible verses about Disabled People. https://www.openbible.info/topics/disabled_people

Oyeniyi, B. (2019). The History of Libya. Santa Barbra Denver, CO: GREENWOOD.

Pasquale, F. (2018). The "Other" at Home: Deportation and Transportation of Libyans to Italy during the Colonial Era (1911-1943). Cambridge: Cambridge University. https://doi.org/10.1017/S0020859018000299 
Penrose Jr., W. D. (2015). The Discourse of Disability in Ancient Greece. Classical World, 108, 499-523. https://doi.org/10.1353/clw.2015.0068

Ratnikas, A. (n.d). Timelines. Libya. http://www.timelinesdb.com/listevents.php?subjid=109\&title=Libya

Religious Action Center of Reform Judaism (n.d). Jewish Values and Disability Rights. https://rac.org/jewish-values-and-disability-rights

Scalenghe, S. (2014). Disability in the Ottoman Arab World, 1500-1800. Cambridge: Cambridge University Press. https://doi.org/10.1017/CBO9781107045309

Smeltzer, S., Mariani, B., \& Meakim, C. (2017). Brief Historical View of Disability and Related Legislation. Villanova University College.

http://www.nln.org/docs/default-source/professional-development-programs/ace-serie s/brief-history-of-disability.pdf?sfvrsn $=6$

Stahl, N. (2014). AFR 110: Intro to Contemporary Africa. Pennsylvania State University-Instructor Chanda Burrage. https://sites.psu.edu/afr110/2014/09/24/ancient-libya/

Temehu Tourism Services (2019). State of Libya (دولة لييبا). https://www.temehu.com/libya.htm

The Library of Congress Country Studies (2001). Libya the United Nations and Libya. https://www.workmall.com/wfb2001/libya/libya_history_the_united_nations_and_liby a.html

The Minnesota Governor's Council on Developmental Disabilities (2019). A History of Developmental Disabilities. http://mn.gov/mnddc/parallels/one/3.html 